Celtic: A Journal of Culture, English Language Teaching, Literature and Linguistics

Vol. 7, No. 1, June 2020.

E-ISSN: 2621-9158 P-ISSN:2356-0401

http://ejournal.umm.ac.id/index.php/celtic/index

\title{
MBOJO NICKNAMES: REVIEWING THE CLIPPING PROCESS OF BIMANESE PERSONAL NAMES
}

\author{
${ }^{1}$ Rosalin Ismayoeng Gusdian*, ${ }^{2}$ Azizatul Zuhra \\ ${ }^{1}$ Universitas Muhammadiyah Malang, Indonesia \\ ${ }^{2}$ SMP Negeri 02 Woja, Indonesia \\ *Corresponding Author: rosalindedy@gmail.com
}

\begin{abstract}
It is the aim of the study to reveal the distinctive clipping process that takes place in the word formation of nicknames in Mbojo which is one of the major ethnic groups in Bima and its surroundings. Moreover, this study employed qualitative method. The objects of this current study were Mbojo nicknames used by people who live in Dompu Regency, West Nusa Tenggara. The nicknames were collected from the family cards $(K K)$, in 2 community units $(R W)$. The data were supported by an informant who is a native of Dompu regency was requested to validate and check whether the collected nicknames data were truly the local people. In analyzing the data, the researcher classified the collected data using the categorization of clipping process. The result of the study showed that the clipping process found in Mbojo nicknames took place in the beginning of the names (fore-clipping); in the end of the names (back-clipping); in the beginning and end of the names (ambi-clipping); in the middle and end of the names (median-clipping and back-clipping); and in the beginning, middle, and end of the names (fore-clipping, median-clipping, and back-clipping). It is implicated that among these clipping process, ambi-clipping is the most frequently found type in Mbojo nicknames.
\end{abstract}

Keywords: Clipping; Mbojo; Nicknames; Word-formation Process

\begin{abstract}
ABSTRAK
Tujuan dari penelitian ini adalah untuk mengungkapkan proses kliping yang terjadi di dalam pembentukan nama panggilan di Mbojo yang merupakan salah satu kelompok etnis utama di Bima dan wilayah sekitarnya. Desain dari penelitian ini, Peneliti menggunakan metode kualitatif karena peneliti mencoba untuk menggambarkan proses klipping di dalam pembentukan nama panggilan di Mbojo. Adapun objek dari penelitian ini adalah nama panggilan Mbojo yang digunakan oleh masyarakat yang tinggal di Kabupaten Dompu, Nusa Tenggara Barat. Nama-nama tersebut dikumpulkan dari kartu keluarga (KK) yang ada di dua Rukun Warga (RW) yang ada di daerah Dompu. Mereka harus benar-benar dari penduduk local. Oleh karena itu, Data tersebut juga didukung oleh seorang informan yang merupakan penduduk asli Kabupaten Dompu yang mempunyai peran untuk mengecek apakah nama-nama tersebut benar-benar berasal dari penduduk lokal. Kemudian, Dalam menganalisis data, peneliti mengklasifikasikan data yang dikumpulkan menggunakan kategorisasi proses kliping. Selanjutnya, hasil penelitian menunjukkan bahwa proses kliping yang ditemukan di julukan Mbojo terjadi di awal nama (fore-clipping); di akhir nama (back-clipping); di awal dan akhir nama (ambi-clipping); di tengah dan akhir nama (ambi-clipping dan back-clipping); dan di awal, tengah, dan akhir nama (fore-clipping, ambi-clipping, dan back-clipping). Hal Ini berimplikasi bahwa di antara proses kliping ini, kliping ambi adalah jenis yang paling sering ditemukan dalam nama-nama panggilan suku Mbojo.
\end{abstract}

Kata Kunci: Nama Panggilan; Kliping; Mbojo; Proses Pembentukan Kata 
Gusdian, R. I. \& Zuhra, A. (2020). Mbojo Nicknames: Reviewing the Clipping Process of Bimanese Personal Names. Celtic: A Journal of Culture, English Language Teaching, Literature, \& Linguistics, 7(1), 65-73.

\section{INTRODUCTION}

Language is established through naming process (Pateda, 2016). Every single thing in the universe abides names. As stated in Croft (2009) and Coates (2013), names are associated with person, entity, or thing. Therefore, names mean more than just mere words; they refer not only to people but also animals, objects, ideas, and even a brand.

In terms of a person's name, people are used to call others using their nicknames instead of complete names for the sake of flexibility and simplicity Wardhaugh (2006). For instance, in, it is much easier to call someone whose name is 'Alexander Nicholson' with 'Alex' rather than with 'Alexander.' 'Alex' consists of fewer syllables than 'Alexander'; thus, it makes people feel at ease when using such a name. According to Plag (2003), calling people with nicknames indicates closeness or familiarity. People tend to use nicknames to call others whom they are closely related with. Alex, Ben, Rob, Mike, and Kate are examples of nicknames showing that English speakers like to shorten each other's names (Yule 2010). Not only does shortening names take place in English names, but such a phenomenon also happens in other languages. In Bahasa, the names with more than two syllables, like 'Anita' and 'Suharto' are trimmed into 'Ani' or 'Nita' and 'Harto' respectively. In terms of morphology, shortening part(s) of a word is known as clipping. In English, for example, terms like 'gasoline' and 'advertisement', are frequently clipped into 'gas' and 'ad'; while, In Bahasa, common words like 'dokter' and 'kakak' are usually clipped into ' $d o k$ ' and ' $k a k$ '. Yule (2010) examines that clipping is eliminating or slicing one of more than one syllable of a word to a shorter form, usually beginning in casual speech.

Meanwhile, Indonesia is a country which comprises hundreds of ethnic groups speaking various local languages. These ethnic groups, such as Sunda, Minangkabau, Bugis, Java, Sasak, Batak, Madura, and Mbojo, speak their own and distinctive local languages (Sundanese people speak Bahasa Sunda; people of Minangkabau speak Bahasa Minang; Javanese people have their very own Boso Jowo, and others). Among these ethnic groups, Mbojo is an ethnic group of which people reside in Bima, city located in the island of Sumbawa, West Nusa Tenggara; the language they use is also called Mbojo. From the initial observation, in their naming tradition, Mbojo people use certain nicknames to honor the elderly. These nicknames are called lia angi; they are used by younger people to address the elder ones.

Studies which delve into word formation process are numerous (Marzita, Syarif, and Ardi 2013; Ratih and Gusdian, 2019; etc.). Meanwhile, There have been studiesalthough not many-conducted to investigate clipping as word formation process phenomenon in some languages. Dwijayanti (2008) investigated the clipped words produced in a Javanese program aired in the local TV show; Jamet (2009) examined the morphological approach of clipping in English; and Goethem and Hiligsmann (2014) inspected the clipping process in a certain Dutch word 'reuze'. However, the studies about the clipping process in names are very few. Only Fajardo and Gonzalez (2018) delved into the clipping process of personal names in more than twenty different languages; in the findings, they found that there are major types of shortened clipped names (absolute, suffixed, and blending).

Besides, the studies about the naming system in Mbojo are also very limited; only Said (2016) examined the functions of Mbojo nicknames which refer to the cultural aspects. In this study, he found that the nicknames are mainly used to honor older 
Celtic: A Journal of Culture, English Language Teaching, Literature and Linguistics

Vol. 7, No. 1, June 2020.

E-ISSN: 2621-9158 P-ISSN:2356-0401

http://ejournal.umm.ac.id/index.php/celtic/index

people. Another similar study by Julaiha (2016) revealed that the address forms used in Mbojo used several selections of address forms and the vowel change patterns depending upon the addresses' age and gender. These findings showed that address forms found in nicknames in Bima language are affected by age and gender. Female and male have vowel change patterns in the addressing forms.

However, there are fairly limited studies researching on the morphological process of the nicknames in Mbojo naming system. Therefore, this study is going to investigate the word -formation process (specifically the clipping process) taking place in the Mbojo naming system.

\section{METHOD}

The research objects of this study were Mbojo nicknames that are used by Bimanese people living in Dompu. The data were gathered from the family cards $(K K)$ in 2 community units $(R W)$ of Dompu regency. In addition to support the data collection and validation, the native informant of Dompu regency was requested to check whether the collected data were truly the nicknames of the local people. The selection process of the names itself covered two criteria, namely (1) the proper names were first names; and (2) the names had Mbojo nicknames. In analyzing the data, the researcher employed the clipping classification by Aronoff and Fudeman (2011).

\section{FINDINGS AND DISCUSSION}

The process of clipping into Mbojo nicknames is based on the process' place. To understand the process easily, the clipping process were marked by giving red colours on the names.

Table 1. Clipping in the Beginning of the Names

\begin{tabular}{|c|c|c|}
\hline First names & Nicknames & Mbojo Nicknames \\
\hline Ishaka & Haka & Heko \\
\hline$\underline{\bar{H}}$ artati & Tati & Tatu \\
\hline Halimah & Lima & Lamu \\
\hline$\overline{A b} d u l l a h$ & Dula & Dole \\
\hline Aisyah & Isa & Osi \\
\hline
\end{tabular}

The underlined syllables indicated that the those Mbojo nicknames were first produced by the clipping process cut the parts in the beginning of names. Before changing into Mbojo nicknames, the two clipped names (Halimah and Abdullah) were deleted only in the beginning of the names. Although written, "letters H" were in the end of the first names as if its been eliminated, but "letters H" actually did not have the clipping process. This was caused by the position of the "letters $\mathrm{H}$ " as the end of the word was not clear in pronunciation that was not like other consonant letters. Therefore, the "letter $\mathrm{H}$ " is the semi vowel which acts like vowel but not a vowel.

This was also applied in the last name (Aisyah) which clipping process also only happened in the beginning of the name. In writing, the letter $\mathrm{Y}$ in the middle and $\mathrm{H}$ in the end of the names acted as semi vowel. 
Gusdian, R. I. \& Zuhra, A. (2020). Mbojo Nicknames: Reviewing the Clipping Process of Bimanese Personal Names. Celtic: A Journal of Culture, English Language Teaching, Literature, \& Linguistics, 7(1), 65-73.

Table 2. Clipping in the End of the Names

\begin{tabular}{lll}
\hline First Names & Nicknames & Mbojo Nicknames \\
\hline Agus $\underline{\text { Agu }}$ & Hasa & Heso \\
Hasa & Sala & Sile \\
\hline
\end{tabular}

The underlined syllables indicated that the three Mbojo nicknames were first produced by clipping process cut the parts in the end or last part of the names. The difference of this clipping process in those names were clipping process in the first names (Agus and Hasan) that only eliminated one letter (the consonant letter) but for clipping process in the first name (Salahuddin) eliminated more than one letters that was two syllables.

Table 3. Clipping in the Beginning + End of the Names

\begin{tabular}{lll}
\hline First names & Nicknames & Mbojo nicknames \\
\hline Abubakar & Baka & Beko \\
Ridwan & Wa & Weo \\
Arifuddin & Fudi & Fedo \\
Muhammad & Hama & Hima \\
& & \\
\hline
\end{tabular}

The underlined syllables showed that the four Mbojo nicknames were first formed by clipping process cut the parts in the beginning and end of the names. In the end of the first names, the parts that clipped were always one letter and the consonant letters. The clipped names (Arifuddin and Muhammad) should be Fuddin and Hamma, but nobody pronounced the double letters clearly in daily speech, so it sounded like Fudi and Hama.

Table 4. Clipping in the Middle + End of the Names

\begin{tabular}{lll}
\hline First names & Nicknames & Mbojo nicknames \\
\hline Jainab & Jena & Janu
\end{tabular}

The underlined syllables showed that the Mbojo nickname were first formed by clipping process cut the parts in the middle and end of the names.

Table 5. Clipping in the Beginning + Middle + End of The Names

\begin{tabular}{llll}
\hline First names & Nicknames & Clipped names & $\begin{array}{c}\text { Mbojo } \\
\text { nicknames }\end{array}$ \\
\hline Ibrahim & Brahi & $B a$ & Boa \\
Sulaiman & Lema & & Lamu \\
\hline
\end{tabular}

The red colours showed that the two Mbojo nicknames were first formed by clipping process cut each part in the beginning, middle, and end of the names. The name (Ibrahim) was clipped twice then changing into Mbojo nicknames; the process will be explained further. 
Celtic: A Journal of Culture, English Language Teaching, Literature and Linguistics

Vol. 7, No. 1, June 2020.

E-ISSN: 2621-9158 P-ISSN:2356-0401

http://ejournal.umm.ac.id/index.php/celtic/index

\section{Twice Clipping Processes}

The examples of Mbojo nicknames above were mostly produced in the two steps, but as stated before, there is also Mbojo nicknames which were formed through the steps. First, clipping in the first name became the nicknames. These real nicknames were cut again. Then, the clipped names changed into Mbojo nicknames. So, Mbojo nicknames were produced in twice clipping processes.

Here, the process of clipping process in Mbojo nicknames in the three steps were presented as follows:

Table 6. Clipping Process in Mbojo

\begin{tabular}{|c|c|c|c|c|}
\hline First names & Nicknames & Clipped names & \multicolumn{2}{|c|}{ Mbojo nicknames } \\
\hline Abdurrahman & & Durhama & Hama & Hima \\
\hline Burhanuddin & & $\overline{\text { Burh }} a$ & $\mathrm{Ha}$ & Hia \\
\hline Dahlan & & Dahla & $L a$ & Leo \\
\hline
\end{tabular}

Mbojo nicknames above were produced by clipping cut the part in the beginning + end of the names.

Table 7. The Changed-Spelling Clipped Names

\begin{tabular}{lcc}
\hline First names & Nicknames & Mbojo nicknames \\
\hline Jäina & Jna/Jena & Janu \\
Sulaiman & Lma/Lema & Lamu \\
\hline
\end{tabular}

Uniquely, the nicknames were clipped that change into Mbojo nicknames should be Jna and Lma but in this case for both names were added E (a vowel letter) and becoming Jena and Lema to easily pronounce. Because of Indonesian language do not have or pronounce rarely the consonant clusters. This is applied in Indonesian local language such as Mbojo. As stated before, Mbojo language is vocalic language that loving the vowel letters. Therefore, the changed-spelling clipped names also change in pronunciation.

Table 8. The Letter " $Z$ "

\begin{tabular}{llll}
\hline First names & Nicknames & $\begin{array}{c}\text { Clipped } \\
\text { Names }\end{array}$ & $\begin{array}{c}\text { Mbojo } \\
\text { nicknames }\end{array}$ \\
\hline$\underline{\text { Hamzah }}$ & Hamza & $Z a$ & Njau
\end{tabular}

The letter " $Z$ " is not really famous in Indonesian local people like Mbojo so people call HAMZA > ZA as in NJAU because NJA sounded like ZA. 
Gusdian, R. I. \& Zuhra, A. (2020). Mbojo Nicknames: Reviewing the Clipping Process of Bimanese Personal Names. Celtic: A Journal of Culture, English Language Teaching, Literature, \& Linguistics, 7(1), 65-73.

Table 9. The Vowel Changes in Mbojo Nicknames

\begin{tabular}{|c|c|c|c|c|}
\hline First names & Nicknames & $\begin{array}{l}\text { Clipped } \\
\text { names }\end{array}$ & $\begin{array}{c}\text { Mbojo } \\
\text { nicknames }\end{array}$ & $\begin{array}{c}\text { Vowel } \\
\text { change } \\
\text { patterns }\end{array}$ \\
\hline \multicolumn{5}{|c|}{ Female names } \\
\hline $\begin{array}{l}\text { Aisiah } \\
\text { Atia } \\
\text { Aminah } \\
\text { Rugayah } \\
\text { Maani }\end{array}$ & $\begin{array}{l}\text { Sia } \underline{a} \\
\text { Tia } \underline{a} \\
\text { Ming } \\
\text { Gaya } \\
\text { Ani }\end{array}$ & & 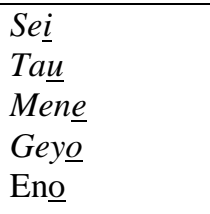 & $\begin{array}{c}A-I \\
A-U \\
A-E \\
A-O \\
\text { I-O }\end{array}$ \\
\hline \multicolumn{5}{|c|}{ Male names } \\
\hline $\begin{array}{l}\text { Burhanuddin } \\
\text { Abdullah } \\
\text { Sulaiman } \\
\text { Dahlan } \\
\text { Hamid }\end{array}$ & $\begin{array}{l}\text { Burha } \\
\text { Dula } \underline{a} \\
\text { Lema } \\
\text { Dahla } \\
\underline{\text { Ham }} \underline{\underline{i}}\end{array}$ & $H \underline{a}$ & $\begin{array}{l}\text { Hia } \\
\text { Dole } \underline{e} \\
\text { Lam } \underline{u} \\
\text { Leo } \\
\text { Him } \underline{a}\end{array}$ & $\begin{array}{c}A-A \\
A-E \\
A-U \\
A-O \\
I-A\end{array}$ \\
\hline $\begin{array}{l}\underline{\underline{\text { ssmail }}} \\
\text { Wahid } \\
\text { Amir } \\
\text { Mahmud } \\
\text { Mansyur } \\
\text { Husen }\end{array}$ & $\begin{array}{l}\text { Ma } \underline{i} \\
\text { Wahi } \\
\text { Ami } \\
\text { Ham } \underline{u} \\
\text { Mansu } \\
\text { Hus } \underline{e} \\
\end{array}$ & $S \underline{u}$ & $\begin{array}{l}\text { Mo' } \underline{i} \\
\text { Wih } \underline{u} \\
\text { Emo } \\
\text { Hima } \\
\text { Sao } \\
\text { Hes } \underline{\underline{o}} \\
\end{array}$ & $\begin{array}{l}I-I \\
I-U \\
I-O \\
U-A \\
U-O \\
E-O \\
\end{array}$ \\
\hline
\end{tabular}

After clipping the first names, the nicknames or clipped names were changed into Mbojo nicknames. Every change when the real nicknames or the clipped names became the Mbojo version that actually have the regular patterns in the change in the final letters of the names. Regular patterns are only in the final vowel letters and have many forms. Regular patterns (vowel change patterns) found in female names were 5 patterns that were A-I, A-U, A-E, A-O, and I-O and regular patterns in male names were many patterns than female names. Regular patterns (vowel change patterns) in male names were 11 patterns that were A-A, A-E, A-U, A-O, I-A, I-I, I-U, I-O, U-A, $\mathrm{U}-\mathrm{O}$, and E-O.

\section{Kinds of Clipping Process}

By knowing the clipping process, we can determine the clipping process into Mbojo nicknames. The kinds of the clipping process in Mbojo nicknames based on the process' place that were indicated by process of clipping. The kinds of clipping in Mbojo nicknames were presented as follows:

\section{Fore-clipping}

Clipping process that delete in the beginning or initial part of the names is labeled ad Fore-clipping. Before changing into Mbojo nicknames, the names were clipped in the beginning of the names that were showed by giving red colours. There were 30 fore-clipping types that were 22 indicated the most found in Mbojo female names and 8 in Mbojo male names. Here were some following examples: 
Celtic: A Journal of Culture, English Language Teaching, Literature and Linguistics

Vol. 7, No. 1, June 2020.

E-ISSN: 2621-9158 P-ISSN:2356-0401

http://ejournal.umm.ac.id/index.php/celtic/index

Table 10. The Example of Fore-clipping

\begin{tabular}{lll}
\hline First names & Nicknames & Mbojo Nicknames \\
\hline$\underline{\text { Ishaka }}$ Hartati & Haka & Heko \\
Jamila & Tati & Tatu \\
& Mila & Male \\
\hline
\end{tabular}

\section{Back-clipping}

Clipping process that delete in the end or final part of the names is labeled Backclipping. Before changing into Mbojo nicknames, the names were clipped in the last part of the names that were also showed by giving red colors. There were 14 backclipping types and only in the male names. Here were some following examples:

Table 11. The Example of Back-clipping

\begin{tabular}{lll}
\hline First names & Nicknames & Mbojo nicknames \\
\hline Agu $\underline{\underline{s}}$ & Agu & Ego \\
Hasan & Hasa & Heso \\
Sala $\underline{\text { huddin }}$ & Sala & Sile \\
\hline
\end{tabular}

\section{Fore-clipping + Back-clipping (Ambiclipping)}

Before changing into Mbojo nicknames, the names were clipped that also underwent the both clipping processes that were fore-clipping and back-clipping.

Table 12. The Example of Fore-clipping + Back-clipping (Ambiclipping)

\begin{tabular}{lll}
\hline First names & Nicknames & Mbojo nicknames \\
\hline$\underline{\text { Abubakar }}$ & Baka & Beko \\
$\underline{\text { Ridwan }}$ & Wa & Weo \\
$\underline{\text { Arifuddin }}$ & Fudi & Fedo \\
Muhamma & Hama & Hima \\
\hline
\end{tabular}

\section{Median-clipping + Back-clipping}

Another combination of clipping process types were found in Mbojo nicknames that were median-clipping and back-clipping. Median-clipping is one of the clipping process that delete in the middle of the names. Before changing into Mbojo nicknames, only 1 name was clipped that underwent the clipping process type and were found in female names. Here was the following example:

Table 13. Median-clipping + Back-clipping

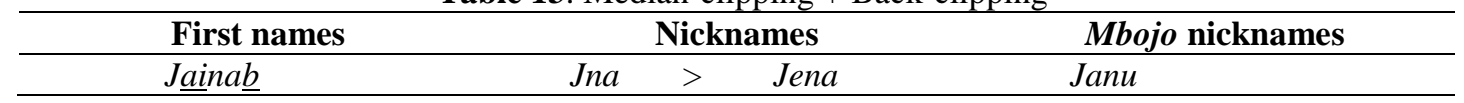

\section{Fore-clipping + Median-clipping + Back-clipping}

Before changing into Mbojo nicknames, the names were clipped that also underwent fore-clipping, median-clipping and back-clipping. There were 2 and found in male names. Here were some following examples:

Table 14. The Example of Fore-clipping + Median-clipping + Back-clipping

\begin{tabular}{lll}
\hline First names & Nicknames & Mbojo nicknames \\
\hline$\underline{\text { Ibrahim }}$ Sulaima $\underline{\text { im }}$ & Ba & Boa \\
\hline
\end{tabular}


Gusdian, R. I. \& Zuhra, A. (2020). Mbojo Nicknames: Reviewing the Clipping Process of Bimanese Personal Names. Celtic: A Journal of Culture, English Language Teaching, Literature, \& Linguistics, 7(1), 65-73.

After analyzing the data, the researcher found that before changing into Mbojo nicknames, the names were clipped that had the various clipping processes, even in one name had three as well as clipping processes. The clipping process found in Mbojo nicknames were in the beginning of the names, in the end of the names, in the beginning + end of the names, in the middle + end of the names, and in the beginning + middle + end of the names while the clipping process were not found in Mbojo nicknames that were in middle of the names, and in the beginning + middle of the names.

As stated before, the kinds of clipping were divided based on the process' place that were showed by the process of clipping. The kinds of clipping process found in Mbojo nicknames, there were clipping process only one type, the combination of two types even the combination of three types. The Mbojo nicknames than can be specified into only 5 kinds of clipping process were fore-clipping, back-clipping, fore-clipping + back-clipping (ambiclipping), median-clipping + back-clipping, and fore-clipping + median-clipping + back-clipping. The 30 Mbojo nicknames were included in foreclipping (22 in female names and 8 in male names), the 14 Mbojo nicknames were included in back-clipping (only in male names), the 78 Mbojo nicknames were included in fore-clipping + back-clipping (ambiclipping) (only in male names), the 1 Mbojo nickname was included in median-clipping + back-clipping (only in female names), and the 2 Mbojo nicknames were included in fore-clipping + median-clipping + backclipping (only in male names).

Furthermore, fore-clipping + back-clipping or ambiclipping was the most dominant type found in this study that were 78 , while median-clipping and backclipping was the rarely type found that was 1 . About gender, mostly female names were undergoing fore-clipping and mostly male names were undergoing fore-clipping + back-clipping or ambiclipping.

\section{CONCLUSION}

The result of the study showed that the clipping process found in Mbojo nicknames that were in the beginning of the names, in the end of the names, in the beginning + end of the names, in the middle + end of the names, and in the beginning + middle + end of the names.

Furthermore, the kinds of clipping process consist of 5 that found from 7 types of the clipping process as in fore-clipping, back-clipping, fore-clipping + back-clipping or ambiclipping, median-clipping + back-clipping, and fore-clipping + median-clipping + back-clipping. The most type used was fore-clipping + back-clipping that was 78 and the lowest type was median-clipping + back-clipping that was 1 only found.

Overall, the study concludes that the clipping process in Mbojo nicknames are rich in patterns as there are not only one type found; instead, several combinations of two and even three types are present in Mbojo nicknames.

\section{REFERENCES}

Aronoff , M., \& Fudeman, K. (2011). What is Morphology? (2 ${ }^{\text {nd }}$ ed.). Malden, MA, USA; Chichester, West Sussex, UK: Wiley-Blackwell.

Coates, R. (2013). Onomastics. In C. A. Chapelle, The Encyclopedia of Applied Linguistics 
Celtic: A Journal of Culture, English Language Teaching, Literature and Linguistics

Vol. 7, No. 1, June 2020.

E-ISSN: 2621-9158 P-ISSN:2356-0401

http://ejournal.umm.ac.id/index.php/celtic/index

Croft, J. B. (2009). Naming the Evil One: Onomastic Strategies in Tolkien and Rowling. Mythlore: A Journal of J.R.R. Tolkien, C.S. Lewis, Charles Williams, and Mythopoeic Literature, 28(1), 149-163.

Dwijayanti, L. (2008). Clipped Words Used in Spells of Mak Bongky Njemunuk Jaya Entertaiment Programs on JTV Surabaya. (Unpublished Undergraduate Thesis). Muhammadiyah Malang University, Malang.

Fajardo, José Antonia Sánchez \& Félix Rodríguez González. (2018). Motivations and Morphological Variations in Clipped Personal Names: A crosslinguistic Approach. Lingua 206: 35-48. doi 10.1016 /j.lingua.2018.01.006

Goethem, Kristel Van \& Philippe Hiligsmann. (2014). When two paths converge: Debonding and clipping of Dutch 'reuze'. Journal of Germanic Linguistics 26(1). 31-64.

Jamet, D. (2009). A Morphophonological Approach to Clipping in English. Can the study of clipping be formalized ?. Lexis Spesial: Lexicology and Phonology, HS 1 | 2009, 15 - 31. doi: 10.4000/lexis.884.

Julaiha. (2016). Gender, Age, and Address Forms in The Bima Language. IJOLT: The Indonesian Journal of Language and Language Teaching, 1(2), 18-24.

Marzita, R., Syarif, H., Ardi, H. (2016). An Analysis of Word Formation Process of English Slang in Teenager Movie Scripts. E-Journal English Language and Literature.2(1),163-173.

Pateda, D. M. (2015). Linguistik Sebuah Pengantar. Bandung: CV Angkasa.

Plag, I. (2003). Word-formation in English. Cambridge, UK: Cambridge University Press.

Ratih, E., \& Gusdian, R.I. (2019). Word Formation Processes in English New Words of Oxford English Dictionary (OED) Online. CELTIC: $a$ Journal of Culture, English Language Teaching, Literature, and Linguistics, 5(2), 24-35.

Said, I. M. (2016). Penggunaan 'Lia Angi": Sapaan Penghormatan Dalam Bahasa Bima. (Doctoral dissertation, Hasanuddin University, Makassar). Retrieved from http://repository.unhas.ac.id/handle/123456789/19721

Wardhaugh, R. (2006). An Introduction to Sociolinguistics $\left(5^{\text {th }}\right.$ ed.). Malden, USA: Blackwell Publishing.

Yule, G. (2010). The Study of Language (4 ${ }^{\text {th }}$ ed.). Cambridge, UK: Cambridge University Press. 